\title{
Pengaruh injeksi nikotin terhadap motilitas, viabilitas, dan integritas membran spermatozoa mencit (Mus Musculus)
}

\section{Effect of nicotine injection on motility, viability, and membrane integrity of mice (Mus Musculus) spermatozoa}

\author{
Kautsar Pandu Pramudita ${ }^{1}$, Widya Paramita Lokapirnasari², Suheni Susilowati ${ }^{3}$, \\ Epy Muhammad Luqman ${ }^{4}$, Hermin Ratnani ${ }^{3}$, Erma Safitri ${ }^{3}$ \\ ${ }^{1}$ Mahasiswa, ${ }^{2}$ Departemen Peternakan, ${ }^{3}$ Departemen Reproduksi Veteriner, \\ ${ }^{4}$ Departemen Anatomi Veteriner \\ Fakultas Kedokteran Hewan, Universitas Airlangga, Surabaya, Indonesia \\ * Penulis koresponden, e-mail: rma_fispro@yahoo.com \\ Open access under CC BY - SA license, Doi : 10.20473/ovz.v9i3.2020.77-81 \\ Received August 5 2020, Revised November 30 2020, Accepted December 22020 \\ Published online December 62020
}

\begin{abstract}
The process of spermatogenesis is sensitive to nicotine, a main component of cigarette smoke. This study aimed to observe the effect of nicotine injection on motility, viability, and membrane integrity of the spermatozoa of mice (Mus musculus). The mice were 10 weeks old, weighing about 20 grams, and in healthy and fertile conditions. Mice were adapted for 1 week by being given feed in the form of pellets and drinking water every day. Twenty of the mice were divided into four groups. Group $\mathrm{K}$ as a control was injected with $0.9 \% \mathrm{NaCl}$ at $2.5 \mathrm{mg} / \mathrm{Kg}$ bw. Group P1 was injected with nicotine at $2.5 \mathrm{mg} / \mathrm{Kg}$ bw. P2 was injected with nicotine at $5 \mathrm{mg} / \mathrm{Kg}$ bw. Group P3 was injected with nicotine at $10 \mathrm{mg} / \mathrm{Kg} \mathrm{bw}$. The injection was carried out subcutaneously as much as $0.5 \mathrm{ml}$ once a day for 35 days. Data analysis used the Analysis of Variances (ANOVA), followed by Duncan's Multiple Range Test. The results showed that the viability, motility, and membrane integrity of the spermatozoa decreased significantly $(\mathrm{p}<0.05)$ according to the increase in the dose of nicotine injected. It could be concluded that subcutaneous nicotine injection linearly decreased the motility, viability, and membrane integrity of the spermatozoa of mice.
\end{abstract}

Keywords: nicotine, spermatozoa, motility, viability, membrane integrity

\section{PENDAHULUAN}

Nikotin banyak digunakan dalam industri rokok sebagai komponen utama karena memiliki sifat addiktif tinggi dan bertanggung jawab menyebarkan perilaku merokok sehingga susah untuk berhenti (Siqueira, 2017). Data WHO yang dirilis Global Youth Tobacco Survey tahun 2014 menunjukkan bahwa prevelensi perokok remaja lelaki pada rentang 13-15 tahun adalah 35,3\%. Catatan World Health Organization (WHO, 2015) menunjukkan jumlah perokok lelaki sebesar $75 \%$ dari total penduduk Indonesia.

Nikotin dapat menyebabkan pembentukan spermatozoa menurun. Spermatozoa merupakan sel reproduksi jantan yang dihasilkan oleh testis.
Secara morfologi spermatozoa memiliki tiga bagian utama terdiri dari kepala, leher, dan ekor. Spermatogenesis adalah proses pembentukan spermatozoa dari sel-sel spermatogonium yang mengalami beberapa kali pembelahan dan differensiasi (Reece et al., 2014). Proses pembentukan spermatozoa sangat sensitif terhadap pengaruh dari luar misalnya yang ditimbulkan oleh asap rokok. Nikotin memiliki partikel yang sangat kecil untuk mengaktifkan sistem imun dan dapat melewati sawar darah otak (Thorn et al., 2017).

Perokok pasif yang terpapar nikotin menyebabkan motilitas spermatozoa menurun karena meningkatkan jumlah lipid peroksida dan menimbulkan kerusakan serta penurunan 
integritas membran spermatozoa sehingga mengurangi motilitas, merusak membran spermatozoa, dan membunuh spermatozoa (Batubara et al., 2013). Nikotin dapat menyebabkan penurunan kadar hormon reproduksi seperti testosteron. Hormon testosteron yang dihasilkan oleh sel Leydig berguna untuk menjaga terjadinya proses spermatogenesis tetap berlangsung (Oyeyipo et al., 2013).

Nikotin juga dapat menyebabkan kerusakan pada organ testis. Kerusakan yang ditimbulkan berupa kacaunya tubulus seminiferus, luruhnya sel germinal epithelium, dan bayaknya sel spermatosit dan spermatid yang rusak akibat proses spermatogenesis yang terganggu. Jumlah sel leydig yang menurun yang dan penebalan dinding arteriol pada tubulus seminiferus juga teramati pada hewan coba yang diberi nikotin (Gawish et al., 2010; Jana et al., 2010). Berdasarkan latar belakang diatas, tujuan penelitian ini adalah untuk mengetahui efek dari injeksi nikotin terhadap motilitas, viabilitas, dan integritas membran spermatozoa mencit jantan.

\section{MATERI DAN METODE}

Penelitian ini menggunakan mencit jantan berumur 3 bulan sebanyak 20 ekor dengan berat 20 gram yang didapat dari Pusat Veteriner Farma Surabaya. Penelitian dilaksanakan berdasarkan persetujuan Komisi Etik Penelitian No 267/HRECC.FODM/VI/2020.

\section{Pemeliharaan hewan coba}

Hewan coba dipelihara dalam Laboratorium Hewan Coba Fakultas Kedokteran Hewan Universitas Airlangga. Hewan coba diadaptasi selama satu minggu dalam kandang yang terbuat dari plastik dengan ukuran $40 \mathrm{~cm}$ x $30 \mathrm{~cm}$ x 12 $\mathrm{cm}$. Alas kandang diberi sekam dan diganti setiap tiga hari sekali. Pelet komersial dan air ledeng diberikan setiap hari.

\section{Pemberian perlakuan}

Hewan coba dibagi kedalam empat kelompok secara acak masing-masing 5 ekor. Kelompok kontrol (P0): injeksi subkutan larutan $\mathrm{NaCl} 0,9 \%$ dosis $2,5 \mathrm{mg} / \mathrm{Kg}$ bb, Perlakuan 1 (P1): injeksi subkutan nikotin dosis $2,5 \mathrm{mg} / \mathrm{Kg}$ bb, Perlakuan 2 (P2): injeksi subkutan nikotin dosis $5 \mathrm{mg} / \mathrm{Kg} \mathrm{bb}$, Perlakuan 3 (P3): injeksi subkutan nikotin dosis $10 \mathrm{mg} / \mathrm{Kg}$ bb. Perlakuan injeksi subkutan dilakukan setelah adaptasi satu minggu dan dilakukan setiap hari selama 35 hari dan dimulai pada pukul 08.00 WIB sampai selesai.

\section{Pengambilan sampel}

Hari ke-36 hewan coba dilakukan euthanasi dengan cara dislokasi cervicalis dan dibedah menggunakan alat bedah untuk diambil testis dan cauda epididimis. Cauda epididimis dipisahkan dengan memotong bagian proximal corpus epididimis dan bagian distal vas defferens. Cauda epididimis yang sudah terpisah diletakkan pada cawan petri berisi $1 \mathrm{ml} \mathrm{NaCl}$ $0.9 \%$. Selanjutnya cauda epididimis dipotongpotong dan diaduk sehingga terbentuk suspensi spermatozoa (WHO, 2010).

\section{Pengamatan motilitas spermatozoa}

Suspensi spermatozoa diteteskan pada object glass dan diamati menggunakan mikroskop dengan perbesaran 400x. Periksa empat lapang pandang hingga mendapat 100 spermatozoa. Pergerakan spermatozoa dinilai menggunakan tiga kategori, yaitu: Progressive motility (PR): Spermatozoa yang aktif baik bergerak lurus atau membuat lingkaran besar bagaimanapun kecepatannya. Non-progressive motility (NP): Berbagai macam gerakan akan tetapi tidak bergerak maju. Immotile (IM): Tidak bergerak sama sekali. Spermatozoa yang normal adalah spermatozoa pada kategori Progresive motilitity (PR).

\section{Pengamatan viabilitas spermatozoa}

Pemeriksaan viabilitas dilakukan dengan memberikan eosin/negrosin pada suspensi dan dibuat preparat ulas setipis mungkin kemudian panaskan diatas nyala api selama 15 detik setelah itu amati dibawah mikroskop dengan perbesaran 400x. Periksa 4 lapang pandang hingga mendapat 100 spermatozoa. Spermatozoa yang terhitung dinilai dalam dua kategori, yaitu spermatozoa yang tidak terwarnai atau bening dan spermatozoa yang terwarnai. Spermatozoa yang normal adalah spermatozoa yang tidak terwarnai atau bening.

\section{Pengamatan integritas membran}

Sebanyak 0,1 $\mathrm{ml}$ suspensi spermatozoa dicampur dengan 0,9 ml larutan HOS Test dan 
diinkubasi pada suhu ruang selama satu jam. Suspensi spermatozoa selanjutnya dibuat preparat ulas dengan pewarna eosin/negrosin kemudian panaskan diatas nyala api selama 15 detik setelah itu amati dibawah mikroskop dengan perbesaran 400x. Empat lapang pandang diperiksa hingga didapatkan 100 spermatozoa. Spermatozoa yang terhitung dinilai dalam dua kategori, yaitu spermatozoa yang mengalami pembengkakan pada ekor atau ekor yang melengkung, dan spermatozoa yang tidak mengalami perubahan. Spermatozoa yang normal adalah spermatozoa yang mengalami peruahan pada ekornya.

\section{HASIL}

Penyuntikan nikotin secara subkutan menyebabkan penurunan viabilitas, motilitas dan integritas membran spermatozoa dibandingkan kelompok kontrol. Dosis nikotin yang lebih tinggi diikuti dengan penurunan secara nyata $(\mathrm{p}<0,05)$ viabilitas, motilitas dan integritas membran spermatozoa (Tabel 1).

Tabel 1 Viabilitas, motilitas dan integritas membran spermatozoa mencit (\%) setelah injeksi nikotin

\begin{tabular}{cccc}
\hline & viabilitas & motilitas & integritas membran $^{\mathrm{d}}$ \\
\hline P0 & $80,60 \pm 1,24^{\mathrm{d}}$ & $81,60 \pm 1,51^{\mathrm{d}}$ & $67,80 \pm 1,78^{\mathrm{d}}$ \\
P1 & $29,20 \pm 1,03^{\mathrm{c}}$ & $52,40 \pm 1,81^{\mathrm{c}}$ & $41,40 \pm 2,07^{\mathrm{c}}$ \\
P2 & $22,00 \pm 1,45^{\mathrm{b}}$ & $20,60 \pm 1,14^{\mathrm{b}}$ & $21,80 \pm 1,92^{\mathrm{b}}$ \\
P3 & $12,80 \pm 1,15^{\mathrm{a}}$ & $13,0 \pm 1,58^{\mathrm{a}}$ & $19,60 \pm 1,14^{\mathrm{a}}$ \\
\hline
\end{tabular}

Superskrip yang tidak sama dalam satu kolom menunjukkan perbedaan nyata $(\mathrm{p}<0,05)$; $\mathrm{P} 0=$ larutan $\mathrm{NaCl} 0,9 \%$ dosis $2,5 \mathrm{mg} / \mathrm{Kg}$ bb; $\mathrm{P} 1=$ nikotin dosis $2,5 \mathrm{mg} / \mathrm{Kg}$ bb; $\mathrm{P} 2=$ nikotin dosis $5 \mathrm{mg} / \mathrm{Kg}$ bb; $\mathrm{P} 3=$ nikotin dosis $10 \mathrm{mg} / \mathrm{Kg}$ bb; injeksi dilakukan secara subkutan setiap hari selama 35 hari.

\section{DISKUSI}

Berdasarkan data yang telah dikumpulkan terlihat bahwa nikotin dapat menyebabkan penurunan motilitas, viabilitas, dan integritas membran spermatozoa normal pada mencit. Hal ini sesuai dengan hasil penelitian sebelumnya bahwa konsentrasi nikotin dalam tubuh dapat menurunkan pergerakan motilitas spermatozoa progresif secara signifikan.Tidak hanya motilitas, tetapi nikotin berperan dalam menurunkan viabilitas spermatozoa pada mencit yang diberi perlakuan (Condorelli et al., 2013). Penurunan motilitas spermatozoa akan diikuti dengan penurunan viabilitas karena spermatozoa yang tidak bergerak dianggap mati karena saat diberi pewarna eosin/negrosin spermatozoa akan terwarnai (Oyeyipo et al., 2011). Hal ini dapat berhubungan karena nikotin dapat menganggu sekresi hormon testosteron. Penurunan hormon testosteron dapat mengganggu proses spermatogenesis sehingga banyak spermatozoa yang mati, atau abnormal (Oyeyipo et al., 2013; Rahmawati, 2013). Pemberian nikotin pada tikus Sprague - Dawley jantan juga menurunkan jumlah sperma (Budin et al., 2017), motilitas sperma, dan viabilitas sperma (Fairuz et al.,
2011) sekaligus meningkatkan persentase sperma dengan morfologi abnormal. Meningkatnya jumlah morfologi sperma yang abnormal setelah paparan nikotin (RahimiMadiseh et al., 2020). Radikal bebas dalam nikotin dapat menginduksi stres oksidatif melalui peroksidasi lipid dan oksidasi protein pada jaringan testis (Budin et al., 2017).

Sebagai radikal bebas, nikotin dapat menyebabkan terjadinya stres oksidasi akibat adanya ketidak seimbangan antara produksi antioksidan dan reactive oxygen species (ROS). Apabila ROS menyerang membran lipid maka akan terjadi lipid peroxidation (LPO) (Henkel, 2011; Takeshima et al., 2018). Terjadinya LPO menyebabkan nikotin menyerang asam lemak tak jenuh untuk menciptakan asam peroksidase radikal. Asam peroksidase radikal akan bereaksi dengan molekul lemak sehingga akan terjadi oksidasi pada membran spermatozoa. Akibat tingginya asam lemak tak jenuh akibat reaksi oksidasi maka membran spermatozoa menjadi rusak. Hasil akhir dari LPO adalah senyawa toksik malodialdehyde (MDA) yang bersifat mutagen sehingga secara tidak langsung merusak DNA (Fitria et al, 2013; Wagner et al., 2018). Nikotin merusak motilitas sperma dan 
memiliki efek merugikan pada fungsi mitokondria sperma, apoptosis dan integritas DNA (Condorelli et al., 2017).

\section{KESIMPULAN}

Injeksi nikotin subkutan dapat menurunkan motilitas, viabilitas, dan integritas membran spermatozoa pada mencit.

\section{DAFTAR PUSTAKA}

Batubara IVD, Wantouw B, Tendean L. 2013. Pengaruh paparan asap rokok kretek terhadap kualitas spermatozoa mencit jantan (Mus musculus). E-Biomedik 1: 330-7.

Budin SB, Kho JH, Lee JH, Ramalingam A, Jubaidi FF, Latif ES, Zainalabidin S, Taib IS, Mohamed J. 2017. Low-dose nicotine exposure induced the oxidative damage of reproductive organs and altered the sperm characteristics of adolescent male rats. Malays J Med Sci. 24: 50-7.

Condorelli RA, La Vignera S, Giacone F, Iacoviello L, Mongioì LM, Li Volti G, Barbagallo I, Avola R, Calogero AE. 2017. Nicotine Effects and Receptor Expression on Human Spermatozoa: Possible Neuroendocrine Mechanism. Front Physiol. 8, 177.

Condorelli RA, La Vignera S, Giacone F, Iacoviello L, Vicari E, Mongioi L, Calogero AE. 2013. In vitro effects of nicotine on sperm motility and bio-functional flow cytometry sperm parameters. Int $\mathbf{J}$ Immunopathol Pharmacol. 26: 739-46.

Fairuz A, Hashida N, Mahanem M. 2011. Effect of nicotine and goat milk co-administration on rat testis and sperm parameters. Austral J Basic Appl Sci. 5: 2738-41.

Fitria F, Triandhini RR, Mangimbulude JC, KarwurFF. 2013. Merokok dan oksidasi DNA. Sains Medika: J Kedokteran dan Kesehatan 5: 113-20.

Gawish M., Ramadan S, Hassan AM, Issa AM. 2010. Morphometrical, Histopathological, and Cytogenetical Ameliorating Effects of Green Tea Extract on Nicotine Toxicity of the Testis of Rats. J Cytol Histol. 1, 105.

Henkel RR. 2011. Leukocytes and oxidative stress: dilemma for sperm function and male fertility. Asian J Androl. 13: 43-52.
Jana K, Samanta PK, De DK. 2010. Nicotine diminishes testicular gametogenesis, steroidogenesis, and steroidogenic acute regulatory protein expression in adult albino rats: possible influence on pituitary gonadotropins and alteration of testicular antioxidant status. Toxicol Sci.116: 647-59.

Oyeyipo IP, Raji Y, Bolarinwa AF. 2013. Nicotine alters male reproductive hormones in male albino rats: The role of cessation. $\mathbf{J}$ Hum Reprod Sci. 6: 40-4.

Oyeyipo IP, Raji Y, Emikpe BO, Bolarinwa AF. 2011. Effects of nicotine on sperm characteristics and fertility profile in adult male rats: a possible role of cessation. $\mathrm{J}$ Reprod Infertil. 12: 201-7.

Rahimi-Madiseh M, Mohammadi M, Hasanvand A, Ahmadi R, Shahmohammadi M, Rostamzadeh A. 2020. Assessment of the toxicity effects of nicotine on sperm and IVF and the potential protective role of silymarin - an experimental study in mice. Middle East Fertil Soc J 25, 14.

Rahmawati I. 2013. Pengaruh Nikotin terhadap jumlah sel Leydig pada mencit (Mus musculus). Stomatognatic, JKG Unej. 10: 82-5.

Reece JB, Urry LA, Cain ML, Wasserman SA, Minorsky PV, Jackson RB, Campbell NA. 2014. Campbell Biology. Tenth Ed. Pearson Publisher. 1045-51.

Siqueira LM. 2017. Committee on substance use and prevention. Nicotine and Tobacco as Substances of Abuse in Children and Adolescents. Pediatrics 139, e20163436.

Takeshima T, Kuroda S, Yumura Y. 2018. Reactive oxygen species and sperm cells. Dalam: Intechopen. Reactive Oxygen Species (ROS) in Living Cells.

Thorn, JM, Bhattacharya K, Crutcher R, Sperry J, Isele C, Kelly B, Yates L, Zobel J, Zhang L, Davis HL, McCluskie MJ. 2017. The effect of physicochemical modification on the function of antibodies induced by antinicotine vaccine in mice. Vaccines 5, 11.

Wagner H, Cheng JW, Ko EY. 2017. Role of reactive oxygen species in male infertility: An updated review of literature. Arab $\mathbf{J}$ Urol.16:35-43.

World Health Organization. 2010. WHO Laboratory Manual for the Examination and Processing of Human Semen. 5th ed. Geneva: World Health Organization. 
World Health Organization, Regional Office for South-East Asia. 2015. Global Youth Tobacco Survey: Indonesia report, 2014. New Delhi: WHO-SEARO. 